\title{
Реконструкция праславянского списка Сводеша
}

\begin{abstract}
Статья является попыткой реконструировать 100-словный список Сводеша для праславянского языка на основании материала 18 славянских языков (как живых, так и мёртвых), включая язык древненовгородских берестяных грамот. Окончательный список, представленный в статье, разделён на 4 группы: 1) праславянское слово сохранилось во всех славянских языках; 2) праславянское слово сохранилось в большинстве славянских языков, в тех, в которых не сохранилось, очевидна поздняя инновация; 3) в отдельных языках/подгруппах представлены различные слова, определить праславянское можно только при помощи внешнего сравнения; 4) стопроцентно определить слово праславянское нельзя даже при помощи внешнего сравнения. Особое внимание в статье уделено третьей и четвёртой группам.
\end{abstract}

Ключевые слова: лексикостатистика, праславянский язык.

Важной задачей как для лексикостатистики, так и для палеославистики представляется реконструкция праславянского списка Сводеша. Сравнение его со списками отдельных славянских языков может послужить хорошей базой для проверки постулатов лексикостатистики, а полученные в итоге этого сравнения результаты могут найти применение в славистике.

Нами были составлены стословные списки Сводеша по восемнадцати славянским языкам, и на их основании проведена реконструкция праславянского списка Сводеша. Кроме того, при реконструкции использовались также древненовгородские формы, почерпнутые из берестяных грамот - полноценный стословный список по грамотам пока, к сожалению, составить не удаётся.

Старославянский список Сводеша составлен методом сплошной выборки из «Старославянского словаря» (далее СС). В старославянском списке отсутствуют семь слов кора, перо, печень, вошь, нос, круглый и жёлтый.

Древнерусские лексемы настолько, насколько это возможно, снабжены ссылками на, к сожалению, пока не оконченные «Словарь русского языка XI-XVII вв.» (далее СРЯ 11-17) и «Словарь древнерусского языка XI-XIV вв.» (далее СРЯ 11-14). В случае если слово не успело войти в СРЯ $11-17$, ссылка даётся на «Материалы для словаря древнерусского языка по письменным памятникам» И. И. Срезневского. Древненовгородские лексемы выбраны из словоуказателя к берестяным грамотам в книге А. А. Зализняка «Древненовгородский диалект», а их значение проверено по грамотам на сайте «Древнерусские берестяные грамоты», содержащем полный корпус найденных грамот.

Древнечешский список Сводеша был составлен при помощи материалов сайта Vokabulář webový, принадлежащий Институту чешского языка Академии наук Чешской республики, на котором в электронном виде представлены все основные словари древнечешского языка.

Древнепольские формы выбраны частично из пока не завершённого Słownika polszczyzny XVI wieku (далее SP 16). Формы, ещё не успевшие войти в данный словарь, 
снабжены ссылками на Słownik etymologiczny języka polskiego В. Борыся, в котором, как правило, старопольская форма приводится в начале словарной статьи.

Кашубский материал выбран из словаря Б. Сыхты, но приведён в соответствие с современной кашубской орфографией.

Полабский список был составлен методом сплошной выборки по шеститомному этимологическому словарю Т. Аера-Сплавинского и К. Полянского (далее SEJDP). В полабском списке Сводеша отсутствуют всего два слова - живот и солнцее.

Верхне- и нижнелужицкие лексемы снабжены ссылками на историко-этимологический словарь Г. Шустер-Шевца.

Болгарские глаголы приведены в форме 1-го лица ед. ч. настоящего времени, македонские в форме 3-го лица ед. ч. настоящего времени, глаголы остальных языков даны в формы инфинитивов.

В списки Сводеша отдельных славянских языков вносились слова, которые являются базовыми, нейтральными и немаркированными обозначениями понятий из эталонного списка. К сожалению, синонимии не всегда возможно избежать (поэтому, например, в список вносятся как рус. зола, так и рус. пепел, как чеш. kоиг̆, так и чеш. dým).

Основным критерием определения того, какое именно слово следует занести в праславянский список Сводеша при наличии нескольких возможных вариантов, является этимологический (внешнее сравнение), вспомогательным - дистрибуционный, согласно которому предпочтение следует отдавать слову, распространённому в большем количестве ветвей данной языковой группы. Дистрибуционный менее надёжен в силу того, что существующее распределение может сложиться благодаря параллельным изменениям в отдельных языках (см. сложную картину распределения рефлексов *slyšati и *čuti в славянских языках) - как независимым, так и вызванным контактами.

Отдельную проблему представляют восемнадцать глаголов списка, поскольку не совсем понятно, формы какого вида вносить в список - совершенного, несовершенного или же обе. Мы решили в качестве решающего фактора в данном случае выбрать морфологический критерий: если формы однокоренные, не вносить в список морфологически производную (т. е. кусать, а не укусить или есть, а не съесть). В случае с глаголами сидеть, стоять и лежать, инфинитивы которых выглядят вторичными по отношению к сесть, стать и лечь, следует принять во внимание, что, если учесть настоящее время, то первичными окажутся именно формы несовершенного вида - сижу, стою и лежу, в отличие от форм с носовым инфиксом - сяду, стану, лягу. И, наконец, у двух глаголов видовые пары образуются супплетивно - приходить / прийти и говорить / сказать. В первом случае мы сочли необходимым внести в список оба компонента видовой пары. Во втором случае, следуя из [Kassian et al. 2010: 75], вносим обозначения только однократного речевого акта.

Весь получившийся список можно поделить на группы:

1) праславянское слово сохранилось во всех славянских языках;

2) праславянское слово сохранилось в большинстве славянских языков, в тех, в которых не сохранилось, очевидна поздняя инновация;

3) в отдельных языках/подгруппах представлены различные слова, определить праславянское можно только при помощи внешнего сравнения;

4) стопроцентно определить праславянское слово нельзя даже при помощи внешнего сравнения.

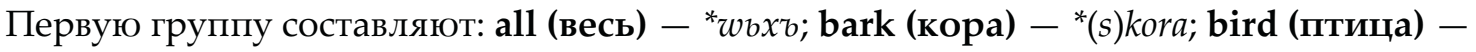
*prta; black (чёрный) - * ${ }^{*} ь r n z b(j b)$; blood (кровь) - ${ }^{*} k r y$; bone (кость) - ${ }^{*} k o s t b$; die (умереть) - *merti; drink (пить) - * piti; dry (сухой) - *suxb(jb); ear (ухо) - *uxo; earth (зем- 
пя) - *zemb; eat (есть) - *е̌sti; egg (яйцо) - *aje; feather (перо) - *pero; fish (рыба) *ryba; fly (дететь) - *letěti; give (дать) - *dati; go (идти) - *jbti; hand (рука) - * roka; head

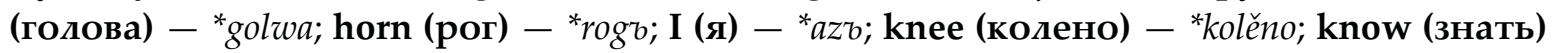

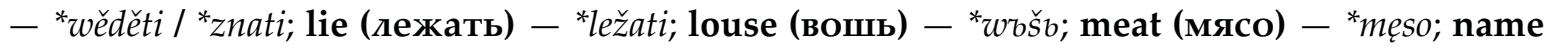
(имя) - ${ }^{*}$ jъmę; new (новый) - ${ }^{*} n o w b(j b)$; night (ночь) - ${ }^{*}$ noktb; nose (нос) — ${ }^{*}$ nosb; not (не) - *ne; one (один) - *edinъ / *edønb; root (корень) - *kory; sand (песок) - *pěsъkb; sit

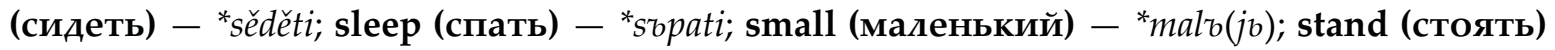

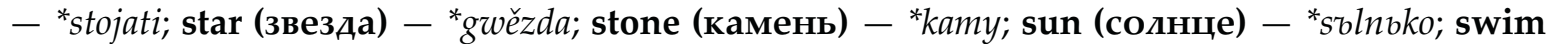
(плавать) - * pluti; tongue (язык) - ${ }^{*} e z k k b$; tooth (зуб) - * zqbb; two (два) - *dvwa; warm (тёпдый) - *teplø(jb); water (вода) - *woda; we (мы) - *my; white (бедый) - *bělb(jb); who (кто) - * $k$; ; уоu (ты) - *ty. Всего 52 .

Вторая группа: ashes (зола) - *pepelø / *popelъ (иннов.: рус. зола́ (наряду с пе́neл)); big (большой) - *welv(jb) (иннов.: болг. голя́м; мак. голем; рус. большо́й; польск. duży (наряду с wielki)); cloud (облако) - *ob-wolka / *ob-wolko / *ob-wolkь (иннов.: укр. хма́pa; кашуб. blóna; полаб. tǫco; в.-луж. mróčel; заимств.: рус. о́блако; бел. во́блака); соте (прийти, приходить) *jbti / *xoditi (иннов.: сербохорв. до̀лазити (наряду с дó һu); заимств.: полаб. komot); dog (собака) - *pbsь (иннов.: болг. ку́че; мак. куче; рус. соба́ка; укр. соба́ка; бел. саба́ка); еуе (глаз) *oko (иннов.: рус. глаз); fire (огонь) - ${ }^{*} о g n ’ b$ (иннов.: сербохорв. вӓтра); foot (нога) - *noga

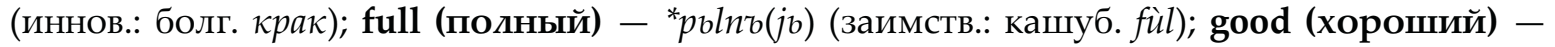
*dobrb(jъ) (иннов.: рус. хоро́ший); green (зелёный) - *zelenъ(jъ) (заимств.: полаб. grönӗ); hair (волос) - *wolsb (иннов.: болг. ко́съм; мак. коса; сербохорв. ко̀са); heart (сердце) - ${ }^{*} s b r d b k o$ (иннов.: полаб. zaivåtək; в.-луж. wutroba; н.-луж. wutšoba; заимств.: бел. сә́рц̧а; польск. serce); kill (убить) - *biti (иннов.: в.-луж. morić; н.-луж. moriś); leaf (дист) - *listı (иннов.: в.-луж. łopjeno; н.-луж. łopjeno); liver (печень) - *etro (иннов.: болг. черен дроб; мак. ирн дроб; рус. пе́чень; укр. печі́нка; бел. пе́чань; словацк. рес̌ег̆; др.-польск. watroba; польск. wątroba; кашуб. watroba); long (длинный) - *dolgzb(jb) (иннов.: рус. дли́нный); man (мужчина) - *možь (иннов.: укр. чоловік; словацк. chlap (наряду с тиž); кашуб. chtop; заимств.: полаб. t’arl / t’arål); man (человек) - *̌élowěks (иннов.: укр. люди́на); many (много) - *mъnоgо (иннов.: укр. бага́mo; бел. шмат, бага́ma (наряду с мно́zа); словацк. vel’a (наряду с mnoho); др.-польск. wiele (наряду с mnogo); польск. dużo, wiele; кашуб. dużo, wiele; полаб. vilĕ; в.-луж. wjele (наряду с mnoho); н.-луж. wjele); moon (пуна) - *luna, *měsękь (иннов: др.-польск. księżyс (наряду с miesiac); польск. księżyc; полаб. t’ènodz (наряду с launa / laina); mountain (гора) - *gora (иннов.: болг. планина́; мак. планина; сербохорв. планиेна); mouth (рот) - *usta (иннов.: др.русск. рzтz; рус. pom; укр. pom; бел. pom; кашуб. gęba; в.-луж. ert, huba); nail (ноготь) *nogъtь (иннов.: бел. пазно́zац̧ (наряду с но́zаць); др.-польск. paznogié́ / paznokieć; польск. paznokieć; кашуб. paznokc (наряду с nokc)); rain (дождь) - *dtžз̌ь (иннов.: сербохорв. ӥиша); red (красный) - *čerw(l’)enъ(jb) (иннов.: словен. rdёс̆; рус. кра́сный; заимств.: бел. чырво́ны; др.-польск. czerwony / czyrwony; польск. czerwony; кашуб. czerwòny (наряду с czerwiony)); round (круглый) - *kroglb(jb) (иннов.: мак. тркалезен / тркалест; чеш. kulatý (наряду с okrouhlý); в.-луж. kulojty; н.-луж. kulaty); see (видеть) - *widěti (иннов.: мак. гледа; заимств.: укр. ба́чити; бел. ба́чьцць); seed (семя) - *sе̌mę (иннов.: укр. насіни́на; польск. паsiono; заимств.: бел. насе́нне; полаб. zot); skin (кожа) - *koža (иннов. др.-польск. skóra (наряду с kuża); польск. skóra; кашуб. skóra); smoke (дым) - *dymъ (иннов.: чеш. kouř (наряду с dým); в.-луж. kur; н.-луж. kuŕ); tree (дерево) - *derwo (иннов.: болг. дърво́; мак. дрво; сербохорв. дриво; чеш. strom; словацк. strom; полаб. dǫ; заимств.: бел. дрә́ва; в.-луж. štom; н.-луж. bom); what (что) *čb (иннов.: болг. каквó); woman (женщина) - *žena (иннов.: польск. kobieta; кашуб. biatka); yellow (жёлтый) - *žъltъ(jъ) (иннов.: словен. rumёn; заимств.: полаб. gale). Всего 35. 
Естественно, наибольший интерес вызывают третья и четвёртая группы. Остановимся на них поподробнее.

\section{Третья группа}

\section{belly (живот)}

Ст.-слав. чр'вво [CС: 784]; болг. коре́м; мак. трбув; сербохорв. тр̀бух; словен. trébuh; др.русск. чєрєво [Срезневский, 3: 1500]; рус. живо́т; укр. живіт; бел. жыво́т; др.-чеш. břисh / br̆ucho; чеш. břicho; словацк. brucho; др.-польск. brzuch / brzucho [SP 16, 2: 478-480]; польск. brzuch; кашуб. brzëch [Sychta, 1: 77]; полаб. —; в.-луж. brjuch; н.-луж. brjuch / brjucho [Schuster-Šewc, 2: 68].

B [Kassian et al. 2010: 52] значение данной лексемы уточняется как «часть туловища между грудью и пахом».

В старейших памятниках старославянского языка слов с таким значением два - чрьво и жтрова. Однако А. С. Аьвов полагает, что отсутствие смысловой разницы между этими словами - явление характерное для Супрасльской рукописи и более поздних памятников старославянского языка. В наиболее древних же чрњво имеет значение «живот», а жтрова - «внутренности» [Дьвов, 1966: 272-279]. Поэтому в список мы вносим только чр'вв. Болгарское коре́м заимствовано, скорее всего, из дунайско-булгарского [БЕР, 2: 633]. Сербохорватская, словенская и македонская лексемы представляют собой инновацию с тёмной этимологией. А. Брюкнер считает возможным родство со словом торба [Brueckner, 1985: 567-568], против чего возражает М. Фасмер, который, в свою очередь, предлагает видеть здесь сложение *trb-buxъ, т. е. «очень набухший» [Фасмер, 4: 96]. П. Скок выводит из сложения *tbr-br'uxъ, якобы означавшего «три живот» [Skok, 3: 495]. Современные восточнославянские формы восходят к др.-рус. животъ, которое однако прежде означало «жизнь, живое существо, домашний скот, имущество», а в современном значении впервые зафиксировано лишь в XVI веке [СРЯ 11-17, 5: 103-104]. Западнославянские формы восходят к праслав. *br'uxо.

Мы признаем исконным слово *̌̌erwo, поскольку оно, видимо, продолжает индоевропейский и ностратический корни с тем же значением [ОСНЯ, 1: 338-339]. Связь между *čerwo и прусским kērmens не случайна (с обычной заменой $-m$ - на -w- в праславянском). И хотя В. Н. Топоров отказывает прусскому слову в значении «живот» [Топоров, 3: 326-331], вполне вероятно, что в прабалтийском живот изначально обозначался именно словом *kerm-, вытесненным в латышском и литовском и изменившим значение на «тело» в прусском.

\section{bite (кусать)}

Ст.-слав. Хапдти [СС: 759]; болг. ха́nя; мак. каса; сербохорв. грйсти; словен. grísti; др.русск. коусати [СРЯ 11-17, 8: 144], [СРЯ 11-14, 4: 340]; рус. куса́ть; укр. куса́ти; бел. кусáųь; др.-чеш. kúsati; чеш. kousat; словацк. hrýzt’; др.-польск. kęsać [SP 16, 10: 259-260]; польск. kasać; кашуб. grëzc [Sychta, 1: 361]; полаб. kosӗt [SEJDP, 2: 283]; в.-луж. kusać; н.-луж. kusaś [Schuster-Šewc, 10: 738-739].

Старославянское хапати и болгарское ха́nя восходят к звукоподражательным славянским глаголам *xapati / *xapiti [ЭССЯ, 8: 18-19], который, по всей видимости, означал «хватать» [Derksen, 2008: 202].

Формы остальных языков восходят либо к * ${ }^{*} r y s t i$ (1. sg. praes. * $\left.{ }^{*} r y z q\right)$ (сербохорватский, словенский, словацкий, кашубский), либо к *kosati (1. sg. praes. *kosajo). Географическое распределение форм, а также их балтийские соответствия говорят в пользу того, 
что исконным является *kesati, a *grysti представляет собой локальную позднейшую инновацию.

\section{breast (грудь)}

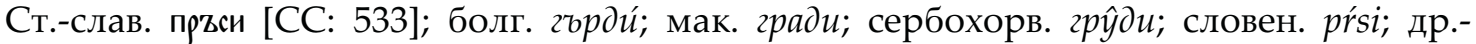
русск. гроудь [СРЯ 11-17, 4: 145-146], [СРЯ 11-14, 2: 396]; рус. грудь; укр. гру́ди; бел. гру́дзі; др.-чеш. prsa, hrud'; чеш. prsa, hrud'; словацк. hrudník; др.-польск. pirśs > pierś / piérś [SP 16, 24: 90-94]; польск. pierś; кашуб. piers [Sychta, 4: 255]; полаб. börst’a [SEJDP, 1: 47-48]; в.-луж. hrudź; н.-луж. gruźa [Schuster-Šewc, 5: 353].

B [Kassian et al. 2010: 54] рекомендуется вносить в список лексему со значением «человеческая грудь как передняя часть туловища между шей и животом». При этом, «если в языке есть общий термин, обозначающий как мужскую, так и женскую грудь, рекомендуется выбирать именно его. В противном случае следует брать обозначение мужской груди. Отличать от конкретизированного обозначения женских молочных желез или сосков, от внутренних органов (лёгкие и т. п.) и от грудной (рёберной) клетки».

Следуя этой рекомендации, мы вносим в список не чеш. hrudník - část trupu mezi krkem a břichem [Slovník spisovné češtiny, 2010: 103], и не ňadra - ženské poprsí, lidská hrud', prsa [Slovník spisovné češtiny, 2010: 196], a prsa - přední část hrudníku, hrud' [Slovník spisovné češtiny, 2010: 318] и менее частотное hrud’ - přední část hrudníku, prsa [Slovník spisovné češtiny, 2010: 103].

Полабское börst’’ заимствовано из ср.-нем. borst [SEJDP, 1: 47-48]. Лексемы остальных языков восходят либо к *pbrsb либо к * grodb. Поскольку слово * grodb представляет собой инновацию «возвышение» > «выступающая часть тела» > «грудь», то праславянским обозначением груди было, по всей видимости, *porsb, имеющее родственников в других индоевропейских языках.

\section{burn (жечь)}

Ст.-слав. жєшти [CС: 216]; болг. горя́, па́ля; мак. пали; сербохорв. жећи; словен. žgáti; др.русск. жєчи [СРЯ 11-17, 5: 99], [СРЯ 11-14, 3: 254]; рус. жечъ; укр. палити; бел. паліиъ; др.чеш. páliti; чеш. pálit; словацк. pálit’; др.-польск. palić / pálić [SP 16, 23: 35-39]; польск. palić; кашуб. pôlëс [Sychta, 4: 15-16]; полаб. zazat < *žbžati [SEJDP, 6: 1060-1062]; в.-луж. palić; н.-луж. paliś [Schuster-Šewc, 14: 1038].

Все формы восходят либо к *̌̌ekti (1. sg. praes. *̌̌ego), либо к *paliti. Индоевропейские параллели этих двух лексем заставляют предположить, что *žekti в данном значении первично.

\section{cold (холодный)}

Ст.-слав. стоудєнъ [СС: 631]; болг. студе́н; мак. ладен, студен; сербохорв. хла́дан; словен. hláden; др.-русск. -; рус. холо́днъй; укр. холо́дний; бел. хало́дны; др.-чеш. studený; чеш. studený; словацк. studený; др.-польск. —; польск. zimny; кашуб. zёmni [Sychta, 6: 214]; полаб. zaimna [SEJDP, 6: 1051-1052]; в.-луж. zуmnу; н.-луж. zymny [Schuster-Šewc, 23: 1771].

В данном случае важно отличать «прохладный» и «холодный». Для списка Сводеша подходит только второе [Kassian et al. 2010: 55]. В болгарском первому соответствует хладен [Бернштейн, 1966: 699], второму - студен [Бернштейн, 1966: 638]. В польском языке первому соответствует chłodny (mający niską temperaturę, ale niezbyt zimny) [Wielki słownik języka polskiego, 2008: 100], а второму zimny (mający niską temperaturę, taki, w którym panuje niska temperatura) [Wielki słownik języka polskiego, 2008: 971]. В чешскому первому chladný (mající nízkou teplotu, (mírně) studený) [Slovník spisovné češtiny, 2010: 
107], второму - studený (mající nízkou teplotu, vyvolávající pocit zimy, velmi chladný) [Slovník spisovné češtiny, 2010: 420]. Аналогична чешской ситуация в словацком: chladný - bez tepla, studený (op. teplý) [Slovník slovenského jazyka, 1: 557-558], studený - majúcí nízku teplotu, bez tepla, vzbudzujúcí dojem chladu, vel'mi chladný [Slovník slovenského jazyka, 4: 310-311]. В старославянском хлдаььн означало «прохладный» [CС: 761]. В значении «холодный» редко встречалось слово зимьнъ [СС: 236] и куда чаще стоудєнъ [CС: 631], которое мы и вносим в список.

Явную инновацию «зимний» > «холодный» демонстрируют лехитские и лужицкие языки. Этимология заставляет считать, что значение «холодный» в праславянском было при-

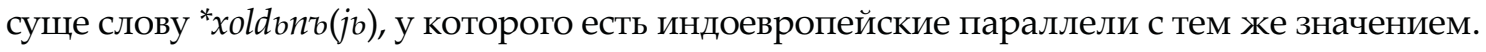

\section{fat (жир)}

Ст.-слав. тоукъ [CС: 708]; болг. мазнина́; мак. маснотија; сербохорв. масно̀ћа; словен. mâst; др.-русск. тоукъ [Срезневский, 3: 1036]; рус. жир; укр. жир; бел. тлушч; др.-чеш. tuk; чеш. tuk; словацк. tuk; др.-польск. tuk [Boryś, 2005: 652-653]; польск. ttuszcz; кашуб. tłuszcz [Sychta, 5: 355]; полаб. toik [SEJDP, 5: 842]; в.-луж. tuk; н.-луж. tuk [Schuster-Šewc, 20: 1556].

Во всех случаях мы старались вносить наиболее общее слово. Например, болгарское мазнина означает жир вообще, а тльстина только животный жир, в список мы вносим первое. Аналогична ситуация с македонскими маснотија и маст. В русском с начала XVII века жирь, означавшее раньше «богатство, достаток, пастбище», стало фиксироваться в значении «fat» [СРЯ 11-17, 5: 113]. Польское и кашубское ttuszcz (< ${ }^{*}$ trlstjb) происходит от праслав *trlstr(jb) «толстый» [Boryś, 2005: 636]. Белорусское тлущu, несомненно, заимствовано из польского.

Почти наверняка «жир» обозначался в праславянском словом *tukb. Оно имеет балтийские параллели и распространено в значении, близком к праязыковому во всех славянских языках

\section{hear (слышать)}

Ст.-слав. слышати [CС: 615]; болг. чу́вам; мак. слуща; сербохорв. чйти; словен. slíšati; др.русск. слышати [СРЯ 11-17, 25: 147-148]; др.-новг. цюти / чюти [грамоты № 154, 1420-1430 гг., № 314, 1380-1400гг.]; [грамоты № 705, 1200-1220 гг., № 870, 1120-1140 гг.]; рус. сльímamь; укр. чу́mu; бел. чущъв; др.-чеш. slyšе̌ti; чеш. slyšet; словацк. pос̌ut'; др.-польск. styszeć [Boryś, 2005: 561]; польск. styszeć; кашуб. сzёс; полаб. slausə [SEJDP, 5: 719-720]; в.-луж. styšé́; н.-луж. styšaś [Schuster-Šewc, 17: 1310].

Исконно, видимо, *slyšati, поскольку оно имеет индоевропейские параллели с тем же значением, в то время как *̌̌uti - инновация «чувствовать» > «слышать».

\section{road (дорога)}

Ст.-слав. пжть [CС: 562]; болг. пъm; мак. nam; сербохорв. nу̂m; словен. се́sta; др.-русск. Аорога [СРЯ 11-17, 4: 323], [СРЯ 11-14, 3: 58-59]; др.-новг. поуть [грамота № 390, 12801300 гг. и др.]; рус. доро́za; укр. доро́zа; бел. даро́zа; др.-чеш. cěsta / ciesta, dráha; чеш. cesta; словацк. cesta; др.-польск. droga / dróga [SP 16, 6: 29-47]; польск. droga; кашуб. droga [Sychta, 1: 243-244]; полаб. pot [SEJDP, 4: 567-568]; в.-луж. puć [Schuster-Šewc, 16: 1187], dróha; н.луж. droga [Schuster-Šewc, 3: 173-174].

Формы всех языков восходят к трём лексемам - *dorga, *cěsta и *potb. *dorga происходит от *dbrgati [ЭССЯ, 5: 74-75], *cěsta - от *cěstiti [ЭССЯ, 3: 188-189]. Оба слова пережили сдвиг значения «расчищенная» (тропа) > «дорога». Слово *potb, имеющее многочисленные индоевропейские параллели, несомненно, древнее. 


\section{that (тот)}

Ст.-слав. тъ [СС: 708-710], онъ [СС: 412-413]; болг. о́нзи; мак. оној; сербохорв. та̂j, òнаj; словен. tîsti, ôni; др.-русск. тъ > тотъ [Срезневский, 3: 1058], онz [СРЯ 11-17, 12: 377378], [СРЯ 11-14, 6: 130-132]; др.-новг. тъ > тотъ [грамоты № 247, 1025-1050 гг., № 605, 1100-1120 гг. и мн. др.]; рус. тот; укр. той; бел. той; др.-чеш. on, onen; чеш. tamten; словацк. tamten; др.-польск. on; польск. tamten; кашуб. tamten [Sychta, 5: 319]; полаб. to [SEJDP, 5: 847-849]; в.-луж. tamny, tamón; н.-луж. tamny, tamski [Schuster-Šewc, 20: 1498].

В старославянском указательных местоимений было три: сь, тZ и онz. Местоимение сь указывало на близкий предмет, онъ на отдалённый, «тъ противопоставлялось сь, но без подчёркивания отдалённости того, на что указывается» [Вайан, 2007: 168-169]. В список мы вносим сь и онz. В сербском и словенском для указания на близкий предмет используется оваj, tâ, более далёкий - maj, tîsti, самый далёкий - oнaj, ôni.

В западнославянских языках представлена явная инновация - tamten.

Согласно А. Мейе, в праславянском была трёхчленная система [Мейе, 1951: 353], соответствующая праиндоевропейской в бругмановском представлении. Признавая справедливость мнения Мейе, мы вносим в список местоимения *tъ, указывавшее на объект, находящийся рядом с собеседником, и *оъ, указывавшее на объект вне связи с говорящим и слушающим.

\section{this (этот)}

Ст.-слав. сь [CС: 676-677]; болг. то́зи; мак. овој; сербохорв. овај; словен. tâ; др.-русск. сь > сєй [СРЯ 11-17, 24: 35-36]; др.-новг. сь > сєи [грамоты № 247, 1025-1050 гг., № 752, 901 1100-1120 гг. и мн. др.]; рус. э́тот; укр. изей; бел. zámbl; др.-чеш. sen, ten, tet; чеш. ten; словацк. ten; др.-польск. ten; польск. ten; кашуб. ten [Sychta, 5: 342]; полаб. so [SEJDP, 5: 743744]; в.-луж. tón; н.-луж. ten [Schuster-Šewc, 20: 1515-1516].

Праславянским местоимением в данном случае было *sb [Мейе, 1951: 353-354].

\section{Четвёртая группа}

\section{neck (шея)}

Ст.-слав. шиґ [СС: 790], выњ [СС: 161]; болг. шиял, врат; мак. врат; сербохорв. враิт; словен. vrât; др.-русск. воротъ [СРЯ 11-17, 3: 34], [СРЯ 11-14, 1: 477], шьљ > шєн [Срезневский, 3: 1596]; рус. ше́я; укр. шиял; бел. шьія; др.-чеш. krk; чеш. krk; словацк. krk; др.-польск. szyja [Boryś, 2005: 610]; польск. szyja; кашуб. szёja [Sychta, 5: 244]; полаб. vojo / voja [SEJDP, 6: 1034]; в.-луж. šija; н.-луж. šyja [Schuster-Šewc, 12: 1436].

В случае с чешским и словацким в список следует внести krk (část těla spojující hlavu s trupem [Slovník spisovné češtiny, 2010: 151]; čast těla spojujúca hlavu s trupom, hrdlo [Slovník slovenského jazyka, 1: 774]); a He vaz (zadní část krku [Slovník spisovné češtiny, 2010: 484]) и šíje (zadní část krku, vaz, týl [Slovník spisovné češtiny, 2010: 432]) / šija (zadná al. horná čast’ pliec a krku [Slovník slovenského jazyka, 4: 407]). В польском наблюдается обратная ситуация, в список следует внести слово szyja (u człowieka i niektórych zwierząt: część ciała łącząca głowę z tułowiem [Wielki słownik języka polskiego, 2008: 804]), a нe kark (tylna część szyi granicząca z plecami [Wielki słownik języka polskiego, 2008: 316].

В целом, формы всех языков восходят к праслав. *wortъ, *wbja, “šbja, *kbrkb. Вероятно, локальной инновацией является чешско-словацкое $k r k$, восходящее к праслав. * $k b r k b$, которое, по мнению авторов ЭССЯ [ЭССЯ, 14: 218-219], продолжает праиндоевропейское название шеи и родственно др.-инд. krkātam «шея» и галльск. cricon «горло» либо проис- 
ходит от глагола *kbrčiti [ЭССЯ, 14: 209-211] «корчить, крутить», который, в свою очередь, является продолжением п.-и.-е. ${ }^{*} k r k$ - «экспрессивное образование, передающее

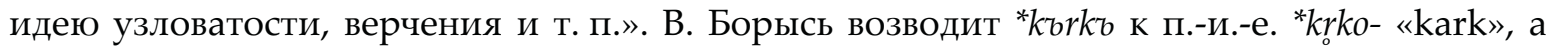
его, в свою очередь, к *(s)ker-k- «крутить, вращать» [Boryś, 2005: 223]. Довольно показательна в данном отношении славяно-осетинская изоглосса: слав. ${ }^{*} k b r k b-$ осет. $x \bar{u} r x / x o r x$ «горло, глотка» [Абаев, 1965: 20].

Скорее всего, инновационно также *wortъ, распространённое, в основном, в южнославянских языках. Из оставшихся двух лексем в силу большей географической распространённости на роль праславянского слова neck подходит *š øja.

\section{say (сказать)}

Ст.-слав. рєшти [CС: 580-581]; болг. ка́жа; мак. каже; сербохорв. рѐћu; словен. réс̌i; др.русск. рєчи [СРЯ 11-17, 22: 157-158], съказАти > сказати [СРЯ 11-17, 24: 165-168]; др.-Новг. рєчи [грамоты № 879, 1120-1140, № 656, 748, 1160-1180 гг. и др.], съказАти [грамота № 725, 1180-1200 гг.]; рус. сказа́mь; укр. сказа́ти; бел. сказа́u̧ь; др.-чеш. ř́ci; чеш. říci / ř́ct; словацк. povedat; др.-польск. powiedzieć [SP 16, 29: 113]; польск. powiedzieć; кашуб. rzec [Sychta, 6: 377], powiedzec [Sychta, 6: 154]; полаб. ricat [SEJDP, 4: 640-641]; в.-луж. rjec; н.-луж. rjac [SchusterŠewc, 16: 1222].

Следуя рекомендациям из [Kassian et al. 2010: 75], в список нужно вносить слова, являющиеся нейтральными обозначениями однократного речевого акта.

По всей видимости, исконным было * $r e k t i$ (1. sg. praes. * rekq). В польском и словацком оно было вытеснено континуантами глагола *powédati «сообщить». В этих языках сохраняются слова rzec и riect' соответственно, носящие книжный характер [Słownik poprawnej polszczyzny, 2010: 688], [Slovník slovenského jazyka, 3: 742]. В кашубском сохраняются оба глагола. В восточнославянских языках и в болгаро-македонской группе *rekti был вытеснен глаголом *(sb)kazati «показывать».

\section{tail (хвост)}

Ст.-слав. опашь [CС: 414], ховотъ [CС: 762]; болг. опа́шка; мак. опашка; сербохорв. pên; словен. гёр; др.-русск. хвостъ [Срезневский, 3: 1366], опашь [СРЯ 11-17, 13: 12], [СРЯ 11-14, 6: 136]; рус. хвост; укр. хвіст; бел. хвост; др.-чеш. ocas, chvost; чеш. ocas; словацк. chvost; др.польск. ogón [SP 16, 21: 98-101], chwost [SP 16, 3: 376]; польск. ogon; кашуб. ògón [Sychta, 3: 294-295]; полаб. våpaus / våpais [SEJDP, 6: 939-940]; в.-луж. wориг̌; н.-луж. wориц̌, wogon [Schuster-Šewc, 22: 1658; 21: 1639].

Сербохорватское ре̂n и словенское гёр восходят к праслав. * rzap, род. п. rzapia «зад, хвост», чешск. диал. г̌ap, řáp «ручка», в-луж. rjap, н.-луж. rе̌ṕ «позвоночник» [Bezlaj, 3: 171], [Skok, 3: 128-129]) и, по-видимому, в данном значении являются инновацией. Русское диалектное репица «задняя часть туловища лошади, круп», очевидно, не связано с данным корнем и происходит от слова репа, о чём говорят как фонетика, так и семантика данного слова, поскольку кроме лошадиного крупа оно может обозначать также собственно репу

Слова *ogonъ [ЭССЯ, 26: 231-232], *očesъ, *opašь / *opaša [ЭССЯ, 28: 167], *opušs [ЭССЯ, 29: 42], *ošibs / *ošibr [ЭССЯ, 30: 133] - поздние региональные инновации, образованные от глаголов с приставкой *ob- от глаголов *ob-goniti «обгонять», *ob-cěstiti «очистить», *ob-paxati «обмести», *ob-pušiti «опушить», *ob-šibiti / *ob-šibati «бить».

Остаются *xobotb и *xwostb. Этимологическая неясность последнего, наличие у него родственников в других индоевропейских языках, а также его большая географическая распространённость (в значении «хвост» или производном от него названии растения 


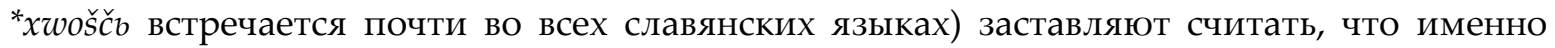
слово *xwostb означало tail в праславянском. Лексема *xwostъ значительно древнее и распространённее. В. М. Иллич-Свитыч возводит его к п.-и.-е. * ${ }^{*}$ ues-t- «ветвь, листва» [Иллич-Свитыч, 1961: 96]. В. Махек полагает, что первоначальным значением этого слова было «веник, которым хлещут в бане», вследствие чего был образован глагол *xwostati «хлестать, парить в бане веником» [Machek, 1968: 211]. Так как хвостом тоже хлещут, *xwostb распространилось на него.

Таким образом, благодаря многочисленности славянской группы языков и наличию в ней языка, крайне близкого к праславянскому, праславянский список Сводеша удалось составить с относительно высокой точностью, но не для всех слов из списка в правильности выбора можно быть полностью уверенным, что, конечно же, должно быть учтено при дальнейшей работе с данным списком.

\section{Питература}

АБАев В. И. Скифо-европейские изоглоссы. М.: Наука, 1965. [AвAEv V. I. Skifo-evropejskie izoglossy. M.: Nauka, 1965.] БЕРНШтЕЙН С. Б. Болгарско-русский словарь. М.: Советская энциклопедия, 1966. [BERNSHTEJN S. B. Bolgarskorusskij slovar'. M.: Sovetskaya enciklopediya, 1966.]

Български етимохогичен речник. Томове I-VI. София: Издателство на Българската Академия за науките, Академично издателство «Проф. Марин Дринов», 1971-2002. [Balgarski etimologichen rechnik. Tomove IVI. Sofiya: Izdatelstvo na Balgarskata Akademiya za naukite, Akademichno izdatelstvo «Prof. Marin Drinov», 1971-2002.]

ВАЙАН А. Руководство по старославянскому языку. М.: Издательство ЛКИ, 2007. [VAJAN A. Rukovodstvo po staroslavyanskomu yazyku. M.: Izdatel'stvo LKI, 2007.]

Аревнерусские берестяные грамоты. Режим доступа: http://gramoty.ru/ [Dreonerusskie berestyanye gramoty. Rezhim dostupa: http://gramoty.ru/]

ЗАлизняк А. А. Аревненовгородский диалект. М.: Языки славянской культуры, 2004. [ZALIZNYAK A. А. Drevnenovgorodskij dialekt. M.: Yazyki slavyanskoj kul'tury, 2004.]

Илдич-Свитыч В. М. Один из источников начального $x$ - в праславянском (Поправка к «закону Зибса») // Вопросы языкознания, 1961, № 4. С. 93-98. [Illich-Svitych V. M. Odin iz istochnikov nachal'nogo $x$ - v praslavyanskom (Popravka k «zakonu Zibsa») // Voprosy yazykoznaniya, 1961, № 4. S. 93-98.]

ОСНЯ - Илдич-Свитыч В. М. Опыт сравнения ностратических языков: Сравнительный словарь. Тома I-III. M.: Наука, 1971-1984. [ILLICH-SvitYCH V. M. Opyt sravneniya nostraticheskikh yazykov: Sravnitel'nyj slovar'. Toma I-III. M.: Nauka, 1971-1984.]

Пьвов А. С. Очерки по лексике памятников старославянской письменности. М.: Наука, 1966. [L'vov A. S. Ocherki po leksike pamyatnikov staroslavyanskoj pis'mennosti. M.: Nauka, 1966.]

Македонско-русский словарь. М.: Астрель - АСТ, 2003. [Makedonsko-russkij slovar'. M.: Astrel' - AST, 2003.]

Мвйе А. Общеславянский язык. М.: Издательство иностранной литературы, 1951. [MеJе A. Obscheslavyanskij yazyk. M.: Izdatel'stvo inostrannoj literatury, 1951.]

СРезневскИЙ И. И. Материалы для словаря древнерусского языка по письменным памятникам. Тома I-III. СПб.: Типография Императорской Академии Наук, 1893-1912. [SREZNEVSKIJ I. I. Materialy dlya slovarya drevnerusskogo yazyka po pis'mennym pamyatnikam. Toma I-III. SPb.: Tipografiya Imperatorskoj Akademii Nauk, 1893-1912.]

СРЯ 11-14 - Словарь древнерусского языка (XI-XIV вв.). Тома 1-8. М.: Русский язык, 1988-2008. [Slovar' drevnerusskogo yazyka (XI-XIV vv.). Toma 1-8. M.: Russkij yazyk, 1988-2008.]

СРЯ 11-17 - Словарь русского языка XI-XVII вв. Выпуски 1-28. М.: Наука, 1975-2008. [Slovar' russkogo yazyka XI-XVII vv. Vypuski 1-28. M.: Nauka, 1975-2008.]

СС - ЦЕЙТАИН Р. М., ВЕЧЕРКА Р., БЛАГОВА Э. Старославянский словарь. М.: Русский язык, 1994. [TSEJTLIN R. М., VECHERKA R., BLAGOVA E. Staroslavyanskij slovar'. M.: Russkij yazyk, 1994.] 
Толстой И. И. Сербско-хорватско-русский словарь. М.: Государственное издательство иностранных и национальных словарей, 1958. [TOLSTOJ I. I. Serbsko-khorvatsko-russkij slovar'. M.: Gosudarstvennoe izdatel'stvo inostrannykh i nacional'nykh slovarej, 1958.]

Топоров В. Н. Прусский язык. Тома I-V. М.: Наука, 1975-1990. [Toporov V. N. Prusskij yazyk. Toma I-V. M.: Nauka, 1975-1990.]

ФасмеР М. Этимологический словарь русского языка. Тома I-IV. М.: Прогресс, 1964 - 1973. [FASMER M. Etimologicheskij slovar' russkogo yazyka. Toma I-IV. M.: Progress, 1964 - 1973.]

ЭССЯ - Этимологический словарь славянских языков. Выпуски 1-33. М.: Наука, 1974-2007. [Etimologicheskij] slovar' slavyanskikh yazykov. Vypuski 1-33. M.: Nauka, 1974-2007.]

BEZLAJ F. Etimološki slovar slovenskega jezika. Knjige I-IV. Ljubljana: Mladinska knjiga, 1977-2005.

BORYŚ W. Stownik etymologiczny języka polskiego. Kraków: Wydawnictwo Literackie, 2005.

BRÜCKNER A. Słownik etymologiczny języka polskiego. Warszawa: Wiedza Powszechna, 1985.

DERKSEN R. Etymological dictionary of the Slavic inherited lexicon. Leiden - Boston: Brill, 2008.

Kassian A., Starostin G., Dybo A., Chernov V. The Swadesh wordlist. An attempt at semantic specification // Journal of Language Relation 4 (2010). Pp. 46-89.

SEJDP - LEHR-SPŁAWIŃSKI T., POLAŃSKI K. Słownik etymologiczny języka drzewian połabskich. Zeszyty I-VI. Wrocław - Warszawa - Kraków: Zakład narodowy imienia Ossolińskich - Wydawnictwo PAN, 1962 - 1994.

MACHEK V. Etymologický slovník jazyka českého. Praha: Nakladatelství Československé Akademie Věd, 1968.

SCHUSTER-ŠEWC H. Historisch-etymologisches Wörterbuch der ober- und nidersorbischen Sprache. Bände 1-24. Bautzen: VEB Domowina-Verlag, 1978-1989.

SKOK P. Etimologijski rječnik hrvatskoga ili srpskoga jezika. Knjige I-III. Zagreb, 1971-1973.

Slovník slovenského jazyka. Diely I-VI. Bratislava: Vydavatelstvo slovenskej Akadémie Vied, 1959-1968.

Slovník spisouné češtiny. Praha: Academia, 2010.

SP 16 - Słownik polszczyzny XVI wieku. Tomy 1-34. Wrocław - Warszawa - Kraków: Zakład narodowy imienia Ossolińskich - Wydawnictwo PAN, 1966-2010.

Stownik poprawnej polszczyzny. Warszawa: PWN, 2010.

SYcHTA B. Słownik gwar kaszubskich. Tomy I-VII. Wrocław - Warszawa - Kraków: Zakład narodowy imienia Ossolińskich - Wydawnictwo PAN, 1967-1976.

Vokabukář webový. Режим доступа: http://vokabular.ujc.cas.cz/

Wielki słownik języka polskiego. Kraków: Krakowskie Wydawnictwo Naukowe, 2008.

M. N. SAENKO. Reconstruction of the Proto-Slavic Swadesh wordlist.

The article is an attempt to reconstruct the 100-word Swadesh list for the Proto-Slavic language. It is based on materials of 18 living and extinct Slavic languages including the language of birch-bark letters. The final list presented here is subdivided into 4 parts: 1) ProtoSlavic words preserved in all Slavic languages; 2) Proto-Slavic words preserved in the majority of the Slavic languages, with transparent innovations in the rest; 3) words attested in disparate languages, whose Proto-Slavic origin can be identified only with the help of external comparison; 4) words whose Proto-Slavic origin cannot be identified with $100 \%$ certainty even with the help of external comparison. Lexemes of the third and fourth groups are particularly analysed in the article.

Keywords: lexicostatistics, Proto-Slavic language. 